\title{
ENGLISH TEACHERS' WORK ENGAGEMENT AMONG CRITIQUES OF LOW PROFESSIONAL COMPETENCE IN INDONESIA
}

\author{
Basikin \\ Departement of English Education \\ Faculty of Languages and Arts \\ Yogyakarta State University \\ Email: basikin@gmail.com
}

\begin{abstract}
ABSTRAK
Artikel ini ditulis berdasarkan kajian tentang keterlibatan kerja 152 guru Bahasa Inggris SMP di Yogyakarta. Data dikumpulkan dengan angket model Utrecht Work Engagement Scale (UWES 9) yang dikembangkan oleh Schaufeli dkk. pada tahun 2002, yang mengukur tiga faktor keterlibatan kerja, yaitu semangat, dedikasi, dan ketertarikan. Hasil penelitian menunjukkan bahwa keterlibatan kerja para guru secara umum tinggi (rerata 5,04 pada skala 7; rerata semangat, dedikasi, dan ketertarikan masing-masing 4,99, 5,44, dan 4,71). Reliabilitas data dihitung dengan Cronbach alpha. Koefisien alpha secara keseluruhan adalah 0,91 dan koefisien alpha untuk semangat, dedikasi, dan ketertarikan adalah 0,76, 0,83, dan 0,79. Temuan penelitian ini menarik dalam konteks prestasi siswa dan perhargaan terhadap profesi guru yang rendah.
\end{abstract}

Kata kunci: keterlibatan kerja guru, kemampuan profesional

\section{A. INTRODUCTION}

Issues in teachers' work engagement have received important responses due to the worldwide high attrition and turnover among teachers. This is also due to the belief that work engagement contributes to positive consequences for both individuals and organization (Bakker \& Bal, 2006). In terms of the case of teacher attrition and turnover, especially in the USA, Ingersoll has reported that up to fifty percent of teachers leave teaching profession in the first ten years of their career (Ingersoll, 2001). Li Feng (2005) emphasizes that among those who stayed, only a quarter retired while half of them left for other careers. The case of teacher turnover and attrition also happens in other western countries with $25 \%-40 \%$ of beginning teachers leave their job (Ewing \& Smith, 2003). Similarly, Pillay, et al. (2005) found that $25 \%$ to $40 \%$ of beginning teachers in Western countries are either leaving their job or are burned out (Pillay, Goddard, \& Wilss, 2005).
Compared to those in other countries, the number of teachers leaving their profession in Indonesia is low. The low attrition in teaching profession in Indonesia is firstly shown by the rare cases of teachers switching career, or teachers leaving their jobs. Theoretically speaking, this is surprising because although traditionally teaching profession provides high social status, it provides neither high economic satisfaction nor academic recognition. Most teachers in Indonesia do not earn much money compared to their workload, and they are very often criticized due to the low achievement of the students, especially concerning the students' achievement in the national exam.

Furthermore, the teaching profession does not provide high academic recognition for teachers. Although in some region with certain culture teachers are socially respected, they do not have a privileged status, and are stereotyped as those who are humble, wise but not very smart, and live simply. Rarely do teachers get compliments when their students are successful in their school exams. Instead, parents usually 
refer to the institution outside the school where their children go for additional tutoring. On the other hand, when students experience low academic achievement, teachers are the first to be blamed. The image of the teaching profession is neither attractive nor prestigious in the eyes of the younger generation. Not many top-ranked students choose to be teachers, so that the stereotype of teachers not being very smart is reinforced. In addition, teachers usually come from low to middle socio-economic background and so look upon the work of those in teaching as an opportunity to secure a professional career.

Unlike teacher attrition and turnover which do not seem to be significant issues in Indonesian context, teachers' work engagement is an important aspect of teachers and is worth investigating. This is firstly due to the fact that quality teachers are viewed to be important assets in the context of education in Indonesia. Besides, work engagement has also been instrumental in teacher-related research, especially in response to the problems related to teacher retention and turnover. It has also been important area of research in relation to burnout among teachers.

Furthermore, although teaching profession traditionally has a high social status in Indonesia, it provides neither high financial satisfaction nor high academic recognition. The term "traditionally" here is meant to refer to the value in the society, especially the society with Javanese culture where teachers are considered to know everything and have social wisdom so that people come to seek for advice for their problems. Secondly, because most teachers stay in the profession the whole of their career life, it is worth questioning whether they are really engaged in the teaching profession. Additionally, the fact that many teachers have other jobs strengthens the importance of investigating their professional engagement.

The fact that the teaching profession in Indonesia does not provide good academic recognition stimulates interesting questions related to the reasons behind such low acknowledgement. Common beliefs, especially those built by the media, seem to suggest that low academic recognition of the teaching profession in Indonesia is due to low student achievement which is believed to be mostly caused by the low quality of the teachers. However, such suspicion needs to be tested since student achievement does not solely relate to quality teachers. It is affected by complex interrelated factors comprising the input factors, teaching processes, learning atmosphere, school program, and the curriculum. It is, therefore, important to have a look at what the teachers feel and believe in order to arrive at a more comprehensive conclusion. This study therefore is an attempt to provide empirical data, particularly related to whether the teachers believe that they have the ability to carry out their teaching duties.

A number of research and literature on work engagement has offered somewhat different definitions of what work engagement is (Kirkpatrick, 2007; Schaufeli, Salanova, Roma, \& Bakker, 2002). Kirkpatrick (2007), for example, uses the word job engagement to refer to employee's interest in, enthusiasm for and investment in his or her jo. She further says that empirical studies have revealed that job engagement is associated with various positive behaviors and outcome for both employees and the organization.

Although issues in work engagement among teachers are increasingly important, research in the field seems to be under developed compared to issues on engagement in other professions or issues about other professional characteristics of teaching profession. Engagement among teachers was initially connected to teachers' professional commitment (Buchanan, 1974; Deci \& Ryan, 1985; Kanter, 1968; Mowday, Porter, \& Steers, 1982). In their early discussion, teachers' commitment was defined as affective attachment to goals or values (Buchanan, 1974), psychological bond or identification of individual to an object (Kanter, 1968), and intrinsic or internal motivation (Deci \& Ryan, 1985; Hackman \& Oldham, 1980). 
There is, however, a more recent development in the direction of research in teachers' work engagement. Schaufeli and colleagues, for example, looked at work engagement as a different construct and defined it as a positive, fulfilling, work-related state of mind characterized by vigor, dedication and absorption (Schaufeli et al., 2002). Vigor is characterized by high level of energy and mental resilience while working, the willingness to invest efforts in ones work and persistence in the face of difficulty. Dedication is ones' sense of significance, enthusiasm, inspiration, pride and challenge. Absorption refers to the state in which one is highly concentrated and happily engrossed in works so that $\mathrm{s} /$ he feels time passes quickly and is difficult to detach from work. Engaged teachers, therefore, feel strong and vigorous at work, enthusiastic and optimistic about the work and are very often get immersed in their works. Work engagement, furthermore, is not a momentary and specific state, it is a more persistent and pervasive affective-cognitive state that is not focused on any particular object, event, individual or behavior.

Research has also suggested that level of work engagement is in general affected by personal characteristics, the work place (Brown, 1996; Kahn, 1990, in Kirkpatrick, 2007) and the characters of the work, including job status and job demands. Teachers' engagement might be affected by their personal characteristics like gender, ages, educational background, identity, self-esteem, and the sense of efficacy. Therefore, teachers with clearer identity, higher self-esteem or more efficacious tend to be more engaged in their job. Other factors affecting teacher work engagement might relate to the context of the work, such as types of school and collegial support a teacher.

Kirpatrick (2007) has argued that empirical studies have revealed that job engagement is associated with various positive behaviors and outcomes for both employees and the organization. Other researchers had suggested that the level of work engagement in general is affected by personal characteristics, the workplace (Brown, 1996; Kahn, 1990) and the characteristics of the work, including job status and job demands (Mauno, Kinnunen, \& Ruokolainnen, 2007). Teachers' engagement might be affected by their personal characteristics like identity, self-esteem, and the sense of efficacy. Therefore, teachers with clearer identity, higher self-esteem, and higher sense of efficacy tend to be more engaged in their job (Mauno et al., 2007).

Practically speaking, teachers' work engagement can include the level of energy and efforts teacher put into teaching, the commitment teachers have to teaching and the amount of time teachers spend in teaching. As research has suggested that efficacy affects commitment to teaching (Coladarci, 1992; Evans \& Tribble, 1986), persistence and resilience (Ashton \& Webb, 1986), the amount of time and efforts dedicated to teaching (Burley, Hall, Villeme, \& Brockmeier, 1991; Gibson \& Dembo, 1984; Glickman \& Tamashiro, 1982), greater enthusiasm for teaching (Alinder, 1994; Guskey, 1984; Hall, Burley, Villeme, \& Brockmeier, 1992), it is, therefore, certain that self-efficacy is a predictor of teachers' work engagement.

In terms of the research model, Job Demands-Resources model or JD-R (Bakker, Demerouti, Boer, \& Schaufeli, 2003; Bakker, Hakanen, Demerouti, \& Xanthopoulou, 2007; Hakanen, Bakker, \& Schaufeli, 2006; Mauno et al., 2007; Schaufeli \& Bakker, 2004) is a model that is commonly used in researching work engagement and burnout in a profession. According to this model, there are two broad categories of work characteristics in every profession. They are job demands and job resources.

Job demands are related to physical, psychological, social, and organizational aspects of the job that require sustained physical and/or psychological efforts that lead to certain physiological and/or psychological costs (Demerouti, Bakker, Nachreiner, \& Schaufeli, 2001, p. 501). Although they are not necessarily negative, job demands, i.e. excessive work load, role ambiguity, and job insecurity might 
result in various strain reactions like stress and impaired well-being (Demerouti et al., 2001; Mauno et al., 2007; Schaufeli \& Bakker, 2004). On the other hand, job resources refer to those physical, psychological, social, and organizational aspects of the job that may (a) be functional in achieving work goals, (b) reduce job demands, and (c) stimulate personal growth and development (Demerouti et al., 2001, p. 501).

Research so far has suggested that job demands could lead to exhaustion (Lee \& Ashforth, 1996) which might lead to negative consequences for the organization, such as absenteeism (Bakker et al., 2003) and impaired role performance (Bakker, Demerouti, \& Verbeke, 2004). Job resources, on the other hand, will lead to engagement and positive outcomes, for example dedication and extrarole performance (Schaufeli \& Bakker, 2004).

\section{B. METHODS}

This research is a quantitative research applying the expose-facto design to reveal the contribution of a number of independent variables to the level of teacher work engagement as a dependent variable. There are seven independent variables and one dependent variable involved in this research. Those independent variables are gender, ages, educational background, teacher status, teaching experiences, schools, and the districts, while the dependent variable is the level of work engagement of 152 English teachers in Yogyakarta province.

Target population of this study was secondary school English teachers in Yogyakarta, a province in Indonesia, especially those who were active in the teacher forums. Sample was chosen purposively based on the requirement that the teacher sample should be an English teacher from all four districts and one municipality in the province. To become research subjects, teachers should have attended the competency-based integrated training (CBIT). The training was either conducted by the national office of the Ministry of National Education (MoNE) or one organized by the local office of MoNE. This training was conducted as one activity to prepare teachers for the newly devised competency-based English curriculum in the country. The materials presented in this training covers teachers' English skills, aspects related to the newly issued Curriculum 2004, and specific instructional strategy recommended to implement the curriculum.

A sample of 200 teachers listed in the teacher forums in all the districts and municipality were recruited but only 152 teachers consisting of $52(34.2 \%)$ male and 100 $(65.8 \%)$ female teachers participated in the research, resulting in the response rate of $76.4 \%$. Those participating teachers ranged in their ages from $23-57$ years old. Among the sample, $21(13.8 \%)$ teachers had the teaching experience of less than five years, 68 (44.7\%) teachers had five to fifteen years of teaching experience and $61(40.1 \%)$ teachers had more than fifteen years teaching experience. One hundred and nineteen $(78.3 \%)$ teachers were civil servant teachers, ten $(6.6 \%)$ teachers were fulltime private teachers and twenty (13.2\%) teachers were part time teachers. One hundred and nineteen (78.3) teachers taught in public schools and $33(21.7 \%)$ other teachers taught in private schools. The sample teachers taught from four districts and one municipality in the province, 22 (15.5\%) from Yogyakarta City, 27 (17.8\%) from Sleman regency, 33 (21.7\%) from Kulonprogo regency, 25 (16.4\%) from Bantul regency, and 45 (29.6\%) from Gunungkidul regency.

Teacher work engagement in this research was measured using the short form of Utrecht Work Engagement (UWES 9) developed by Schaufeli et al (Scaufeli, Baker, \& Salanova, 2002). This measure is a three-factor scale consisting of nine items aiming to measure the three dimensions of work engagement- vigor; dedication and absorption. Three items were used to measure each of the dimensions (see Table 1). All nine items are scored in a seven-point Likert-type scale ranging from 1 (never) to 7 (always). 
Table 1. Items to measure the three dimensions of teacher work engagement

\begin{tabular}{|l|l|}
\hline \multicolumn{1}{|c|}{ Dimensions } & \multicolumn{1}{c|}{ Items } \\
\hline Vigor & 1. At my work, I feel bursting with Energy. \\
\cline { 2 - 2 } & 2. At my job, I feel strong and vigorous. \\
\cline { 2 - 2 } & 3. I am enthusiastic about my job. \\
\hline \multirow{5}{*}{ Dedication } & 4. My job inspires me. \\
\cline { 2 - 2 } & 5. When I get up in the morning, I feel like going to work \\
\cline { 2 - 2 } & 6. I feel happy when I am working intensely. \\
\hline \multirow{3}{*}{ Absorption } & 7. I am proud of the work that I do. \\
\cline { 2 - 2 } & 8. I am immersed in my work. \\
\cline { 2 - 2 } & 9. I get carried away when I am working. \\
\hline
\end{tabular}

In the collection of the data, all samples were directly contacted by the researcher at the teacher forum meetings in every district and municipality. In the meetings, the researcher explained the research project and asked the teachers to participate in the research by completing the work engagement survey. Upon requesting the participation, the researcher explained the purposes of the research, the information required in the research, and the significance of their participation. Issues on confidentiality were also discussed in the preliminary explanation. Participation, however, was voluntary, which was signaled with the voluntarily returning the completed questionnaire by the participants together with the participants' consent forms.

The 9-item questionnaire was presented in two versions, the English and Indonesian versions. Participants were asked to use the Indonesian version only to help with their understanding. They were, however, asked to fill in the English version. This was because they were assumed to understand most of the words in the survey, because they were English teachers. The translated version, therefore, was given only to provide support to the teachers in case they had difficulties in understanding the survey.

The analyses on the data covered the descriptive statistics, and the Multifactormultivariate analysis of variance (MANOVA).
MANOVA was used in considerations that this research sought to investigate not only the main effects of the independent variables, but also the interaction effects in the data. By using MANOVA it is hoped that the analysis would be able to compare groups formed by the categorical independent variables within the sample. Besides, by applying the post-hoc test, MANOVA has the ability to provide the possibility of looking further to identify certain independent variables which provide the most effects in differentiating a set of dependent variables. All those seven demographic data were investigated to see their main effects as well as their interaction effects. Due to the limited power, however, only main effects and two-way interaction effects could be computed.

\section{FINDINGS AND DISCUSSION}

From the descriptive analysis, it was found that there were more female teachers in the sample, with most participants of between 31 and 50 years of age, and with more than five years of teaching experience. Few teachers in the sample did not have English teaching background. Participants were from four districts and one municipality in Yogyakarta province teaching mostly in public schools. Table 2 shows the description and distribution of the sample based on the independent variables. 
Table 2. Description and Distribution of Teacher Sample

\begin{tabular}{llll}
\hline Independent Variables & Value labels & $\mathrm{N}$ & $\%$ \\
\hline Gender & Male & 52 & 34 \\
& Female & 100 & 66 \\
\hline Ages & $<30$ & 14 & 9 \\
& $31-40$ & 84 & 55 \\
& $41-50$ & 42 & 28 \\
& $>50$ & 12 & 8 \\
\hline English teaching Background & Yes & 144 & 95 \\
& No & 5 & 3 \\
& No report & 3 & 2 \\
\hline Teaching Experiences & Less than 5 years & 21 & 14 \\
& $5-15$ years & 70 & 46 \\
& More than 15 years & 61 & 40 \\
\hline Teacher status & Part time teachers & 20 & 13 \\
& Civil servant & 122 & 80 \\
& Full time private teachers & 10 & 7 \\
\hline Schools & Public & 119 & 78 \\
& Private & 33 & 22 \\
\hline Districts & Yogyakarta City & 22 & 14 \\
& Sleman & 27 & 18 \\
& Kulonprogo & 33 & 22 \\
& Bantul & 25 & 16 \\
& Gunungkidul & 45 & 30 \\
\hline
\end{tabular}

Results of the present study suggest that work engagement among the junior secondary school English teachers in Yogyakarta province was generally high, with an overall mean of 5.04 and standard deviation of 1.13 on a 7-point Likert-type scale. Interestingly, although the teaching profession did not provide high privilege and financial returns, teachers in the sample reported dedication as the highest among the three components of work engagement with a mean score of 5.44 , followed by vigor with a mean score of 4.99, and absorption with a mean score of 4.71 (see Figure 1). The reliability of the data is also high (alpha $=.91$ overall; alphas $=.76, .83$, .79 respectively for vigor, dedication, and absorption subscales).

Figure 1. Levels of teachers' work engagement

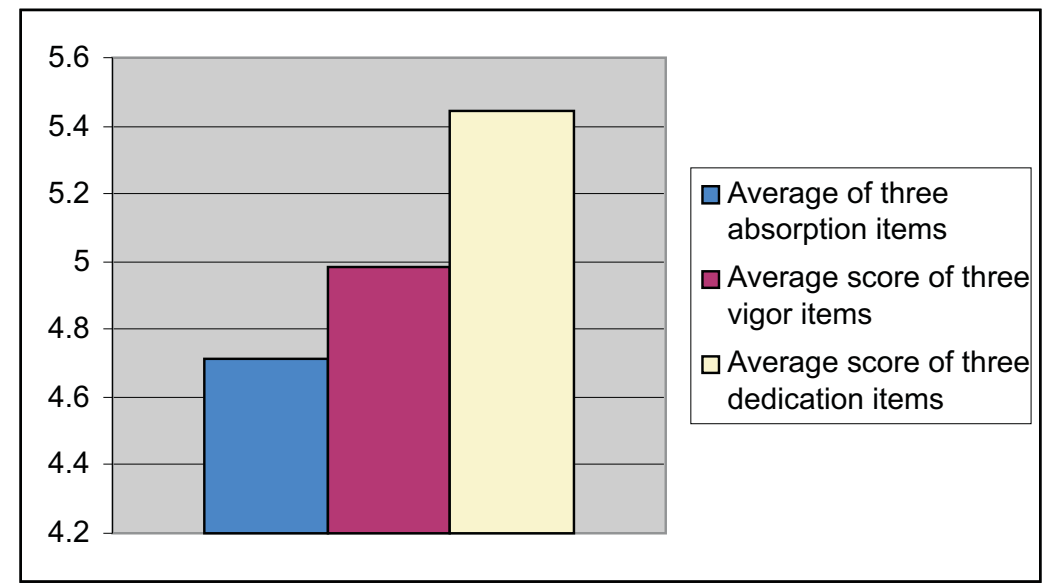

diksi Vol. : 16 No. 2 Juli 2009 
Multivariate test of ANOVA on the data reveals that there is no significant difference in English teachers' work engagement as a result of differences in the independent variables of the research (see Table 3). This means that male teachers are as engaged as the female colleagues in their teaching profession. There is also no significant difference in the work engagement between young teachers and the old ones. Beginning teachers in the sample have the same level of work engagement as that of the more experienced ones. Teacher status, the schools and the districts where the teacher teach do not provide significant contribution to the differences in the work engagement level of the teacher.

Table 3.

Contribution of the independent variables on the differences in teachers' work engagement

\begin{tabular}{clcl}
\hline No. & \multicolumn{1}{c}{$\begin{array}{c}\text { Independent } \\
\text { variables }\end{array}$} & $\begin{array}{c}\text { Contribution to differences in } \\
\text { the teachers' work } \\
\text { engagement }\end{array}$ & \\
\hline 1. & Gender & Not significant & $\mathrm{F}(57,152)=0.176, \mathrm{p}>0.05$ \\
2. & Ages & Not significant & $\mathrm{F}(177,139)=0.983, \mathrm{p}>0.05$ \\
3. & Educational & Not significant & $\mathrm{F}(57,149)=0.131 \mathrm{p}>0.05$ \\
& Background & Not significant & $\mathrm{F}(116,150)=0.305, \mathrm{p}>0.05$ \\
4. & Teaching Experience & Not significant & $\mathrm{F}(116,149)=0.613, \mathrm{p}>0.05$ \\
5. & Teacher status & Not significant & $\mathrm{F}(57,152)=0.442, \mathrm{p}>0.05$ \\
6. & Schools & Not significant & $\mathrm{F}(177,152)=0.914, \mathrm{p}>0.05$ \\
7. & Districts & & \\
\hline
\end{tabular}

Furthermore, the findings also suggest that there is no significant interaction effect among the independent variables on the level of work engagement of the teachers. No significant effects of all independent variables imply that although there might be differences in the means of the sample, such differences happen by chance and do not reflect differences in the population.

It is quite surprising to some extent that there are no significant effects of all independent variables on the work engagement of the teacher sample. This means that all independent variable, either individually or in interaction with other variables do not contribute to differences in the levels of teacher work engagement. Another interesting finding is that, data show that though teaching profession does not provide priviledge and teachers are often blamed for students achievement, teachers in the sample show relatively high level of work engagement. If that is the case, there is a question that needs to be answered. Such question will deal with what factors motivate such level of engagement.

However, before presenting the interpretation on the data gained through the questionnaire, it is important to have a look at the fact that there are not many Indonesian teachers leave their profession before they are at their retirement age. It is also a very rare case in Indonesian context to switch career from nonteaching to teaching because the decision for being a teacher in Indonesia should start very early in one's education history. Primary and secondary school teacher development program starts as soon as one graduates from his/her senior high school. When one wants to be a primary or secondary teacher, there is no other way than entering a teacher college, or a university specially designed to prepare for teachers. Because there is an age limitation to register in such teacher colleges which are normally owned by government, determining teaching career should be very early. 
Teacher retention, therefore, is not a relevant issue when talking about teachers in Indonesia. As explained previously, there is a very little case of quitting teaching, except because of death or retirement. Once recruitment is made, cases of quitting teaching due to bad evaluation result are also very rare. Although teaching profession might be as stressful as one in other countries, it seems that not many people talk about teacher stress and further effects of the stress on the job of teachers in Indonesia. Teachers will remain teachers till the retirement day no matter how stressful their work is.

First interpretation of the high level of engagement among teachers might relate to the social image of teachers in Indonesian, especially in Yogyakarta context. For most members of society, teachers are still considered respected figures, to which society can rely on the role modeling of teachers. Its strong role-model function of teachers is shown by the famous acronym derived from the Javaness word for teacher, guru. Guru in Indonesian means digugu and ditiru. This further means that the society will obey and take models on whatever teachers say and do.

Second, perceived role-model function of teachers seems to be a code of conduct for the teachers themselves in doing not only their academic tasks, but also in behaving in the society. From this, it can be inferred that teachers themselves will consider themselves as society role-models. They thus will make themselves socially acceptable, and build a good image for the society.

In addition, religion seems to be an important factor related to the high level of engagement among teachers in Yogyakarta. As most of the people in Yogyakarta are Moslems, Islamic teachings concerning the duty of spreading knowledge among human being seems to be of great influence. Although the Koran does not explicitly refer to teachers in general, it repeatedly highlights the importance of spreading knowledge and the honor of having 'useful' knowledge, which means that the knowledge is shared with other. Teachers seem to consider the teaching profession not just as a profession, but as a way to achieve a better life hereafter. This idea seems to be a strong determinant of why teachers remain highly engaged in the province.

\section{CONCLUSION, IMPLICATION AND FUTURE DIRECTION OF THE RESEARCH}

Based on the findings of this research, there are several conclusion that the research can draw. First, the level of work engagement among English teachers in the sample is high with an overal mean score of 5.04 on a sevenpoint scale. Among the three factors, dedication is the highest with the mean score of 5.44. Second, such high level of engagement is not derived from the seven independent variables investigated in the this research. In other words, aspects like gender, education background, teaching experience, and the other investigated aspects are not factors influencing the high level of work engagement among teacher sample. Third, regarding the the findings above, it can be speculated that there are other things motivating the high level work engagement. In this case the most relevant speculation is related to the perceived role model function of teachers in the society and religious values held by the sample.

Such role-model function was expected to derive from both social and religious aspects. With respect to the social aspect, teachers consider themselves as models that are expected to be representing the good values in the society. It is, therefore, not good for teachers not to be responsible, in this case engaged, with their work. In addition, from religious point of view, teachers also consider teaching profession a means to search for blessed path of life. Being a teacher is ibadah. With the belief held, teachers seem to take the hereafter rewards to compensate for the low financial returns, and academic recognition.

Worth noting significant limitation of the research, however, is that it was done with the sample of non-certified teachers and at the time when teacher certification was not done. It, 
therefore, sets a limitation that the findings of this research is bound to be understood in such a context. This is because such context might yield different findings from those resulted from the certified teachers or a research done after teachers have a clear expectation of their future in connection with the teacher certification program where the program might change the perception and status of teaching profession. Future research, therefore, can make a use of the current findings to set light on the effect of certification program on teaching profession.

\section{REFERENCES}

Alinder, R. M. 1994. The relationship between efficacy and instructional practices of special education teachers and consultants. Teacher Education and Special Education, 17(2), 86-95.

Ashton, P. T., \& Webb, R. B. 1986. Making $a$ difference. New York \& London: Longman.

Bakker, A. B., \& Bal, P. M. 2006. How work engagement influences performance: Weekly diary study among starting teachers (A manuscript submitted for publication).Unpublished manuscript.

Bakker, A. B., Demerouti, E., Boer, E. d., \& Schaufeli, W. B. 2003. Job demands and job resources as predictors of absence duration and frequency. Journal of Vovational Behavior, 62, 341-356

Bakker, A. B., Demerouti, E., \& Verbeke, W. 2004. Using JD-R to predict burnout. Human Resource Management, 43(1), 83-104.

Bakker, A. B., Hakanen, J. J., Demerouti, E., \& Xanthopoulou, D. 2007. Job resources boost work engagemnet, particularly when job demands are Bakker, A. B., \& Bal, P. M. (2006). How work engagement influences performance: Weekly diary study among starting teachers (A manuscript submitted for publication).Unpublished manuscript.
Burley, W. W., Hall, B. W., Villeme, M. G., \& Brockmeier, L. L. 1991. A Path Analysis of the mediating role of efficacy in first year teachers, experiences, reactions, and plans. Paper presented at the The annual meeting of the American Educational Research Association.

Coladarci, T. 1992. Teacher's sense of efficacy and commitment to teaching. Journal of Exprimental Education, 60(4), 323337.

Demerouti, E., Bakker, A. B., Nachreiner, F., \& Schaufeli, W. B. 2001. The Job Demands-Resources model of burnout. Journal of Applied Psychology, 86(3), 499-512.

Evans, E. D., \& Tribble, M. 1986. Perceived teaching problems, self-efficacy and commitment to teaching among preservice teachers. Journal of Educational Research, 80, 81-85.

Ewing, R. A., \& Smith, D. L. 2003. Retaining quality beginning teachers in the profession English Teaching: Practice and Critique, 2(1), 15-32.

Guskey, T. R. 1984. The influence of change in instructional effectiveness upon the affective characteristics of teachers. American Educational Research Journal, 21(2), 245-259.

Gibson, S., \& Dembo, M. 1984. Teacher efficacy: A construct validation. Journal of Educational Psychology, 76, 569-582.

Glickman, C., \& Tamashiro, R. 1982. A comparison of first year, fifth year and former teachers on efficacy, ego development, and problem solving. Psychology in Schools, 19, 558-562.

Hakanen, J. J., Bakker, A. B., \& Schaufeli, W. B. 2006. Burnout and work engagement among teachers. Journal of School Psychology, 43, 495-513.

Hall, B., Burley, W., Villeme, M., \& Brockmeier, L. 1992. An attemp to explicate teacher efficacy beliefs 
among first year teachers. Paper presented at the The annual meeting of the American Educational Research Association.

Ingersoll, R. M. 2001. Teacher turnover and teacher shortage: An organizational analysis. American Educational Research Journal, 38(3), 499-534.

Kirkpatrick, C. L. 2007. To Invest, Coast or Idle: Second-stage Teachers Enact their Job Engagement. Paper presented at the American Educational Research Association Annual Conference.

Lee, R. T., \& Ashforth, B. E. 1996. A metaanalytic examination of the correlates of three dimensions of job burnout.
Mauno, S., Kinnunen, U., \& Ruokolainnen, M. 2007. Job demands and resources as antecedents of work engagement: A longitudinal study. Journal of Vocational Behaviour, 70, 149-171.

Pillay, H., Goddard, R., \& Wilss, L. 2005. Wellbeing, burnout and competence: Implication for teachers. Australian Journal for Teacher Education, 30(2), $12 \mathrm{pp}$.

Schaufeli, W. B., Salanova, M., Roma, V. G., \& Bakker, A. B. 2002. The measurement of engagement and burnout: A two sample confirmatory factor analytic approach. Journal of Happiness Studies, 3, 71-92. 